УДК 82-98

\title{
СОПОСТАВИТЕЛЬНЫЙ АНАЛИЗ ГАСТРОНОМИЧЕСКОЙ ОБРАЗНОСТИ В РОМАНЕ «КАК СЮЙ САНЬГУАНЬ КРОВЬ ПРОДАВАЛ» И ПОЭМЕ «МЕРТВЫЕ ДУШИ»
}

Инь Тяньлэ

Университет МГУ-ППИ в Шэньчжэне

\begin{abstract}
Аннотация: В статье рассматривается гастрономическая образность в поэме «Мертвые души» и романе «Как Сюй Саньгуань кровь продавал». Автором предпринимается попытка изложения основных функций образов еды.

Ключевые слова: гастрономическая образность, психологическая функция, символическая функция, еда, характер, символ, «Мертвые души», «Как Сюй Саньгуань кровь продавал».

\section{COMPARATIVE ANALYSIS OF GASTRONOMIC IMAGERY IN THE NOVEL CHRONICLE OF A BLOOD MERCHANT AND THE POEM DEAD SOULS}

Yin Tianle

Abstract: The article refers to the gastronomic imagery in the poem Dead souls and the novel Chronicle of a Blood Merchant, the main functions of these images. The main functions of food images are described: psychological, symbolic.

Key words: gastronomic imagery, psychological function, symbolic function, food, character, symbol, Dead souls, Chronicle of a Blood Merchant.

Гастрономическая образность представляет собой значимую составляющую частью не только в жизни, но и в литературных произведениях. Она выполняет определенные функции: продвигает сюжет, характеризует образы персонажей и т.п. 


\section{Гастрономическая образность в романе Юй Хуа «Как Сюй}

\section{Саньгуань кровь продавал»}

«Как Сюй Саньгуань кровь продавал» - роман, написанный в 1995 г. Автор романа - известный современный китайский писатель Юй Хуа. В романе рассказывает о том, что продавая кровь, главный герой Сюй Саньгуань преодолел много трудностей, победил судьбу. Когда он стал уже пожилым человеком, и узнал, что его кровь больше никому не нужна - это сильно подорвало его психику. Писатель точно отразил несчастливую жизнь персонажей, напряженным сюжетом выразил стремление к самосохранению людей, несмотря на то, что в жизни каждого из них поджидает беда.

В романе присутствует ряд гастрономической образности, выполняющей определённые функции.

Первая из них является «водой». В романе четыре характерных момента.

1. Когда герой романа Сюй Саньгуань впервые продал кровь, опытные люди (А-Фан и Гэньлун), продавшие несколько раз, поделились опытом : перед продажей крови необходимо пить не меньше десяти плошек воды, чтобы было много крови. Они обычно пьют речную воду. По их мнению, вверху и на дне реки вода грязная, лучше пить из середины.

2. Старший сын героя поранил сына кузнеца. У героя не было денег, чтобы возмещать. Он опять кровь продал. Однако в этот раз он забыл выпить воду перед продажей. Сразу пил много воды, он думает, что таким образом он не потерял много крови.

3. У А-Фана (друг героя, продавший кровь) пузырь лопнет из-за того, что выпил много воды.

4. Старший сын героя заболел гепатитом, лежал в больнице в Шанхае. Герой отправился на пристань, чтобы плыть в Шанхай. Пароход по дороге останавливался в семнадцати городках, из них шесть были уездными, и Сюй Саньгуань планировал сдать там кровь. На пути он встретился с братьями, которые везли на фабрику в Цилибао коконы шелкопряда. Герой им посоветовал зарабатывать деньги через продажу кровь. И научил их перед продажей больше пить воды.

В романе данная образность выполняет психологическую функцию, отражает характер героя: глупый и невежественный. На самом деле, кровь имеет никакого отношения с водой. Помимо этого, данная образность выполняет символическую функцию. Герой романа - человек низкого происхождения, когда он был бедным, принимал водой за спасительную 228 
соломинку. В этом случае «вода» превратился в воплощение жизни. Герой каждый раз перед продажей крови пил много воды, так как он думал, что вода это тоже самое что и кровь. Чем больше ее пить, тем меньше крови можно терять. Таким образом, «вода» стала символом его жизни.

Вторая из них является «блюдами героя». Из-за «Большого скачка» (Большой скачок - экономическая и политическая кампания в Китае с 1958 по 1960 год, начеленная на укрепление индустриальной базы и резкий подъём экономики страны и имевшая трагические последствия для китайского народа. [1]) всем пришлось быть голодными. Семья Сюй Саньгуаня уже 57 подряд кушала жидкую кашу из кукурузной муки. Он предлагал всей семьёй вместе фантазировать, чтобы утолять жажду. Герой прекрасной речью состряпал семье ужин: приготовил сыновьям тушёное мясо в соевом соусе, принялся за карася в прозрачном бульоне для Сюй Юйлань (жены), приготовил для себя самого жареной печенки.

В романе данная образность выполняет психологическую функцию. Она служит средством характеристики героя, отражает жизнерадостный характер.

Третья из них является печеным бататом. После того, как семья 57 дней подряд кушала кукурузную кашу. Продав кровь, герой решил угостить семью в ресторане несмотря на то, что из-за «Большого скачка» там продавали лапшу. Однако Сюй Саньгуань не хотел вести старшего сына в ресторан из-за того, что первый сын ему родной. Он дал старшему деньги и отправил за печеным бататом. Но хозяин продал ему маленький, даже меньше его ладони, так как он не был взрослым человеком. Бедный мальчик откусил только четыре кусочка, потом бататина кончилась. В конце концов он даже кожуру съел.

В романе данная образность выполняет также психологическую функцию. На самом деле герой больше любил старшего сына, но он родился изза измены жены. Это было позором для него. Одновременно он ненавидит любовника жены. Невинному мальчику необходимо отвечать за все, по мнению героя.

Таким образом, данная образность отражает характер героя противоречивый, он человек, который заботится о своей репутации.

Четвертая из них является печенкой и рисовым вином. Эта образность также связана с опытами вышеупомянутых друзей героя - А-Фана и Гэньлуна. В романе три характерных момента.

1. Когда герой впервые продал кровь, он узнал от друзей, что после продажи крови необходимо употреблять в пищу тарелку печенки и два ляна 
рисового вина, причем вино необходимо подогреть. Как правило, они заказывали блюдо внушительным голосом и жестом: стукнули по столу и крикнули.

2. Когда герой встретился с братьями-лодочниками, он также посоветовал им кушать одно и то же блюдо.

3. Когда Сюй саньгуани было за шестьдесят, он шел по улице мимо ресторана и почуял аромат печенки. Герой захотел еще раз съесть тарелку печенки и два ляна рисового вина, пошел продать кровь. Однако в тот момент его кровь никому не нужна. Думая, что будет делать, если беда придет, он расплакался на улице. Его семья утешила и угостила героя в ресторане. Несмотря на то, что условия жизни стали лучше, он могут все заказать в ресторане, однако, он ещё только хочет такое же блюдо. Жена заказала три тарелки печенки, и герой считает, что это для него самое вкусное.

В романе данная образность выполняет символическую функцию. Она символизирует надежду. Герой живёт продажей крови. Однако количество крови в организме ограниченно, а свиная печенка наполняет организм кровью, вино - оживляет.

Этот единственный способ наполнения крови для таких простых людей, и это отражает трагичность их судьбы. Но одновременно упоминание печенки и рисового вина дает надежду, так как после поглощения такой пищи бедные люди смогут снова кровь продать, это и есть символ надежды в них жизни.

Подводя итог, гастрономическая образность в романе «Как Сюй саньгуань кровь продавал» выполняет психологическую и символическую функции, что способствует продвижению сюжета. Можно сказать, все ряды образности выступают как символ бедной жизни, через такую призму отражается реальность общества в то время. Таким образом, автор создал ряд трагических образов персонажей.

Гастрономическая образность в поэме Н.В. Гоголя «Мертвые души»

«Мертвые души» — главное произведение Н. Гоголя, которое далось ему с огромным трудом, полным надежд, разочарований и отчаяния. В поэме рассказывается о том, как коллежский советник Павел Иванович Чичиков продавал и покупал «мертвые души». Приехав в город NN, Чичиков своими прекрасными комплиментами наладил хорошие отношения с чиновниками разного сословия, а затем отправился на окраину города, чтобы купить у помещиков мертвых крепостных, которые еще не снялись с регистрационного учёта, выдать их за живых, заложить в надзорную комиссию, заполучить 230 
обманным путём огромный залога. Однако обман его вскрыли, ему пришлось спешно покинуть город.

В повести присутствует ряд гастрономической образности, выполняющей функции, о которых речь пойдет в дальнейшем повествовании.

Первая из них появилась во время обеда у Коробочки. Она помещица, второй продавец «мертвых душ» Чичикову. Коробочка хорошо готовила блины разных видов, лепешки со всякими припеками, которые похвалил Чичиков. Однако на самом деле Коробочка хочет, чтобы Чичиков забирал муку.

В повести данная образность выполняет символическую функцию. Она представляет собой символ «шкатулки» помещицы. Всем известно, что Гоголь является мастером «говорящих» имён персонажей. Фамилия помещицы метафорически обозначает сущность её «шкатулки». Она любит класть деньги в ящики. Единственная цель жизни для неё - зарабатывать деньги, она не обращается внимания на остальное. Когда Чичиков предложил купить души, она думала только о цене, что отражает ее характер. Можно сказать, что она сама, как ее фамилия - коробка со слоями, скрывает себя в ящик, равнодушно относится ко всем. Блины по форме похожи на коробку, таким образом, данная образность символизирует сущность персонажа.

Вторая из гастрономических образностей проявляется во время описания сцены обеда у Ноздрева. Он помещик, третий продавец. Еда в жизни Ноздрева играет второстепенную роль: она нужна лишь для того, чтобы удалить голод. Повар у него готовит по вдохновению, всегда кладет первое, что попадется под руку. Зато помещик любит вино. У него вина высокопробные: портвейн, госотерна, модера. Однако когда Чичиков с ним обедал, заметил, что хозяин наливал очень усердно гостям, а себе налил немного.

Данная образность выполняет функцию характеристики персонажа. Повар у помещика готовит не по рецептам, что отражает то, что хозяин драматический, небрежный человек. Этот момент также служит доказательством того, что он не заботится о своих детях. У Ноздрева вина высшего сорта, и он настойчиво угощает вином, видно, что он сам алкоголикскандалист, что является подсказкой грядущего сюжета: Ноздрев раскрыл обман Чичикова. Поэтому вино также выполняет сюжетообразующую функцию. Но когда Ноздрев с Чичиковым обедал, он себе мало налил. Это отражает, что он хитрый человек. Автор привел данный момент и предыдущий фрагмент, где говорится о его подлом поступке в казино, в соответствие. 
Третья образность проявилась во время обеда у Собакевича. Он помещик, четвертый продавец. У него чудовищный аппетит. Когда он кушал в ресторане, только заказывал целые свинину, курицу, гуся... и всё съест, иногда “даже и добавки требовал за ту же цену” [2, с. 33]. Дома на столе больше блюд, но он также все съедал. По мнению Собакевича, ингредиенты у него являются самыми свежими, он кушает, как “душа требует” [3, с. 54]. Блюда у него сильно отличаются индивидуальной особенностью хозяина: Размер ватрушек больше тарелки.

Данная образность выполняет психологическую функцию. Она отражает грубость, неуклюжесть и бездушность персонажи. Собакевич по-медвежьи кушает, что соответствует его говорящей фамилии. Размер блюд у помещика также свидетельствует об этом.

Четвертая из них - во время обеда у Плюшкина. Он пятый продавец. Он угостил Чичикова испорченным хлебом. Рекомендовал соскоблить сверху несвежее, остальное можно съесть. Что касается вина: оно у него не закупоренное, в пыли. Гость спешил, чаем угостил, хозяин сам положил сухарь на то же место, чтобы не украли слуги.

Данная образность выполняет психологическую функцию. С помощью еды автор создал образ яркого скупого спряги. По словам Собакевича, Плюшкин обедает хуже пастуха. Он постоянно ест испорченные еды и все время думает, что слуги у него все украли. Образ помещика олицетворяет омертвение человеческой души, поглощенной болезненной скупостью. Можно сказать, что он живая «мертвая душа». Еда является неотъемлемой частью повседневной жизни. Если человек равнодушен к еде, значит, что хотя он жив, но душа его умерла. Через данный образ автор выразил, что класс помещиков пришел к упадку.

Пятая из них является обедом, устроенным полицеймейстером для поздравления покупки Чичикова. На обеде присутствовали чиновники разного сословия и помещики. Это пир на весь мир, на столе рыбы самых разных видов со стороны рыбного рынка, пироги с различными начинками, например, с головизною, куда вошли хрящ и щеки девятипудового осетра, водки темного оливкового цвета, который похож на сибирские драгоценные камни.

Данная образность выполняет психологическую функцию. Она не только отражает характер полицеймейстера, но и героя Чичикова.

Как написано в поэме, Алексей Иванович наладил хорошие отношения с горожанами, все рыбы из рыбного рынка. Это не значит, что он действительно 
чиновник народу, наоборот, свидетельствует о лицемерии персонажи. Он многоопытный артист, умеет общаться с самыми разными людьми и латентно брать взятки. Здесь автор иронично выразил ненависть к такими чиновниками, создал отчетливое представление о том, что в тогдашнем обществе у чиновников цель единственное - взятки берут. Кроме того, этот обед специально устроен для поздравления Чичикова. Это доказало, что Чичиков умеет польстить каждому, именно поэтому все чиновники с большим удовольствием угостить героя.

Из вышесказанного вытекает, что гастрономическая образность в поэме «Мертвые души» выполняет психологическую функцию, отражая характер персонажей, следовательно, продвигает сюжет. С помощью образов еды автор создал характерные портреты героев поэмы, которые стали составной частью порождения определенного общественного слоя и социального уклада.

Обобщая сказанное, гастрономическая образность в данных произведениях имеет глубокие значения символические и психологические. С помощью образа еды Гоголь сумел отразить пороки крепостнической России и бюрократического общества, а Юй Хуа выразил, главным образом, сочувствие людям невысокого происхождения. Оба писателя описывают еду с другими деталями, что и сделало произведения более выразительными.

\section{Список литературы}

1. 余华. 许三观卖血记 [M]. 北京 : 作家出版社, 2013.

2. https://ru-wikipedia-org.turbopages.org/ru.wikipedia.org/s/wiki/ Большой_скачок

3. 论“水”意象在余华小说中的运用 一以《活着》 《许三观卖血记》 《兄弟》为中心 $[\mathrm{J}]$. 戴娜. 美与时代(下). 2020年02期

4. 雍楠. 探析《许三观卖血记》中的小人物形象 $[\mathrm{J}]$. 兰州 教育学院学报, 2013（1）

5. 陈思和. 中国当代文学史教程 : 第 2 版 $[\mathrm{M}]$. 上海 : 复旦 大学出版社, 2016.

6. 杨辉. 余华与古典传统 $[\mathrm{J}]$. 当代作家评论，2018（2）

7. 童庆炳. 文学理论教程 : 第 5 版 [M]. 北京 : 高等教育出版社, 2015. 
8. Н.В. Гоголь, Собрание сочинений в семи томах, т. 5, ИХЛ, М. 196733 c., $54 \mathrm{c}$.

9. 俄罗斯文学史.俄文版/任光宣, 张建华, 余一中著.一2版.一 北京: 北京大学出版社, 2014.7 .

10. Белинский В.Г.Объяснение на объяснение по поводу поэмы Гоголя «Мёртвые души» [J] // Собрание сочинений в трёх томах Т.П. Статьи и рецензии. 1841-1845. ОГИЗ,ГИХЛ, М., 1948.

11. Ефремова Т.Ф. Новый словарь русского языка. Толковословообразовательный. М: Русский язык, 2000.

12. Журавлев А.П. Звук и смысл [М]. М.: Просвещение, 1991.

13. Калинкин В.М. Поэтика онима [М]. Донецк: Юго-Восток, 1999.

14. 彭铎福. 论赫拉克利特的灵魂观 $[\mathrm{J}]$.湖南教育学院学报, 1995.

15. 果戈理：“作者自白”，沈念驹主编：《果戈理全集》（第六卷），石家 庄：河北教育出版社，2002.

16. 曹靖华，俄国文学史（上卷）.北京:北京大学出版社，2007.（3）

17. 陈冰夷，（苏）季莫菲耶夫主编，俄罗斯古典作家论（上卷）.北京: 人民文学出版社, 1985.

18. 何楚熙, 布留索夫著, 烧成灰的人果戈理特点简评.上海: 复旦大学出版社, 1993.

(C) Инь Тяньлэ, 2020 